\title{
Assessing Telecommunications Competition in the Asia-Pacific
}

Expectations for a successful conclusion to the WTO Doha Development Round of trade negotiations have been raised by Director-General Pascal Lamy's presentation in July 2009 of a "roadmap for autumn negotiations." (www.wto.org/services). While strong support is being given to reaching consensus on new trade commitments in agriculture and manufacturing, there is less certainty regarding services. Although a meeting of trade negotiators from was held to 32 WTO members was held in July 2008, not major progress has been achieved on the services request/offer negotiations. In telecommunications services as well as many other service sectors, a willingness was express by a number of members to improve existing or undertake new, commitments across a range of sub-sectors in both basic and value added services, according to a statement prepared at the Services Signalling Conference.

The International Telecommunication Union (ITU) has prepared a World Telecommunications Regulatory Database presenting the Level of Competition in telecommunications services for jurisdictions in the Asia-Pacific region. (www.itu.int) Telecommunications services are rated according to Monopoly, Partial Competition and Full Competition. An extensive list of services is presented in the rankings: local services, domestic fixed ling long distance, international fixed long distance, wireless local loop, data, DSL, Cable modem, VSAT, Leased lines, Fixed Wireless Broadband, Mobile, Paging, Cable TV, Fixed Sat, Mobile Sat, GMPCS, Internet services and International gateways.

A review of the extent of competition for the 28 WTO member countries and jurisdictions shows that the most developed, including Australia, Japan, Singapore, and Korea, that full competition across the entire range of services. Mid-level developing countries tend to have opened many services to competition, except basic services, and include Bangladesh, Mongo- lia, Thailand, Tonga and Indonesia. Two examples of mid-level developing countries that have opened to full competition, however, are Pakistan and Vietnam. The ITU database shows, however, that less developed countries have maintained public monopolies over the entire range of telecommunications services.

The Asia Pacific Telecommunity (APT) whose members include all of the WTO countries and jurisdictions in the region, sponsors an annual Workshop on Telecommunications Trade Rules to provide officials in regulatory and trade matters to receive briefings on WTO principles and trade rules and review bilateral and regional initiatives. (www.apt.int) The most recent workshop was held in July in Gold Coast, Australia, hosted by the Australian Government Department of Broadband, Communications and the Digital Economy. In addition to presentations on future trends in telecommunications trade negotiations, the role of regulators in telecommunications trade negotiations, and how trade commitments benefit developing countries in terms of investment and other forms of upgrading telecommunications infrastructure and services.

At the workshop representatives of several APT member governments presented reports on their WTO commitments in telecommunications. The following are reports prepared by officials of the Union of Myanmar, Vietnam and Nepal.

\section{Vietnam Commitments in Telecommunications Prepared by Ministry of Information and Communications of Vietnam}

Viet Nam is committed to liberalize most basic Telecom services and some new services.

More liberalized than China's offers in WTO access in 2000 and other countries in ASEAN (except for Singapore) 
Basically, allow foreign investors to take part in Telecom network infrastructure establishment on the condition that Viet Nam's enterprises hold the major captital and control.

Basically, allow foreign investors to hold major capital and controls in some non-facilities based services.

\section{Viet Nam's offers:}

\section{Cross-border supply (international telecom services):}

Wire-based and mobile terrestrial services: Services must be offered through commercial arrangements with an entity established in Viet Nam and licensed to provide international telecommunication services (international normal trade practice)

Satellite-based services: Subject to commercial arrangements with Vietnamese international satellite service suppliers duly licensed in Viet Nam, except satellite-based services offered to:

Upon accession: off-shore/on-sea based business customers, government institutions, facilities-based service suppliers, radio and television broadcasters, official international organization' representative offices, diplomatic representatives and consulates, high tech and software development parks who are licensed to use satellite- earth stations;

Three years after accession: multinational companies, which are licensed to use satellite-earth stations.

Consortium submarines cables: For consortium submarine cable links where Viet Nam is member, foreign service suppliers shall be permitted to control fullyowned submarine cable transmission capacity (e.g. IRU or consortium ownership) terminating at a licensed cable landing station in Viet Nam, and to provide such capacity to international facilities-based service suppliers licensed in Viet Nam. 4 years after accession foreign service suppliers shall be permitted to provide such capacity to international VPN and IXP service suppliers licensed in Viet Nam.

Consumption Abroad: Viet Nam has No Limitation on Market Access and National Treatment.

\section{Commercial Presence:}

Facilities-based services:

Basic services: Upon accession, joint venture with telecommunications service suppliers duly licensed in Viet Nam will be allowed. Foreign capital contribution shall not exceed $49 \%$ of legal capital of the joint ventures
Value-added services: Upon accession, joint venture with telecommunications service suppliers duly licensed in Viet Nam will be allowed. Foreign capital contribution shall not exceed $50 \%$ of legal capital of the joint ventures

\section{Non facilities-based services:}

Basic telecom services and Internet access services: Upon accession joint ventures with telecommunications service suppliers duly licensed in Viet Nam will be allowed. Foreign capital contribution shall not exceed $51 \%$ of legal capital of the joint ventures. Three years after accession: joint venture will be allowed without limitation on choice of partner. Foreign capital contribution shall not exceed $65 \%$ of legal capital of the joint ventures.

Virtual Private Network (VPN) services: Upon accession, joint ventures shall be allowed without limitation on choice of partner. Foreign capital contribution shall not exceed $70 \%$ of legal capital of the joint ventures

Upon accession, joint venture will be allowed without limitation on choice of partner. Foreign capital contribution shall not exceed $51 \%$ of legal capital of the joint ventures. Three years after accession, foreign capital contribution shall not exceed $65 \%$ of legal capital of the joint ventures.

Presence of natural persons: Like other WTO members, Viet Nam reserves the right to have limitations.

\section{Benefits for Viet Nam's telecom sector from those offers:}

Generally speaking, liberalization of Telecom services brings more opportunities for Viet Nam's telecom enterprises:

Enterprises have opportunities to approach broader international market, which involves 150 WTO member countries ( $90 \%$ global population, $95 \%$ global GDP, 95\% global trade value).

Domestic enterprises are able to employ foreign experts and, even, acquire foreign companies.

A clearer Investment Environment will attract greater overseas national currency exchange, which will help speeding up the industrialization and modernization.

Liberalizing Market also creates chances for domestic labors and students to access advanced trainings and educations from big Telecom Corporations.

\section{Negotiations that Viet Nam is involved:}

Besides Bilateral Trade Agreements (BTAs) negotions in the accession to WTO, Viet Nam hasn't been 
involved in any bilateral Free Trade Agreement (FTA) with any country. In the future, perhaps, Viet Nam will consider establishing bilateral FTAs with some strategic partners.

There are some Multilateral FTAs, mostly within ASEAN - ASEAN-Plus FTAs - that Viet Nam has been engaged in, such as:

ASEAN Free Trade Agreement (AFTA) completed in 2003 and entering into comprehensive integration by the establishment of ASEAN Economic Community (AEC) in 2020;

ASEAN-China FTA (ACFTA - since 2002)

ASEAN - Japan FTA (Commenced in 2003 and completed in 2008)

ASEAN - India FTA (Commenced in 2003 and completed in 2009)

ASEAN - Korea FTA (Completed in 2005)

ASEAN - Australia - NewZealand FTA (completed in 2009)

ASEAN - EU FTA (commenced in 2007)

Basically, after accession to WTO, Vietnam always apply WTO commitments as the ceiling (no higher offers) in any other telecom negotiations. In ASEAN, Viet Nam's commitments in WTO are higher than most of other ASEAN countries (except for Singapore), whereas the most important principle in ASEAN is consensus, so in FTA negotiations with ASEAN partners in telecom, normally, Viet Nam is quite advantaged to follow common offers (usually from the most conservative country).

\section{Telecommunications Trade Policy in the Union of Myanmar}

\section{Prepared by Posts and Telecommunications Department}

The Union of Myanmar is a country in the south eastern part of Asia and has a total land area of 676,578 square kilometers, bordering with China, Thailand and Lao PDR to the east and Bangladesh and India to the west. There are 14 states and divisions in Myanmar with Nay Pyi Taw as the new capital. The size of the total population is 57 million.

Telephone density in Myanmar is roughly 2.74 percent. The Ministry of Communications, Posts and Telegraphs is the ministry responsible for Information and Communications Technology development within the country. The ministry is basically made up of two separate departments- the Myanma Posts and Communica- tions (MPT), the state-owned telecommunications operator and the Posts and Telecommunications Department (PTD), the regulatory authority.

Myanmar has been one of the founder members of the WTO since 1st January, 1995. The WTO Telecommunications References Paper covers six broad areas covering Safeguards to prevent Anti-competitive Practices in major suppliers, Interconnection with major suppliers, Universal Service, Transparency in Licensing, Independent Regulator and Allocation and Use of Scare Resources. As United Nation recognizes Myanmar as one of the Least Developing Countries (LDC), Myanmar enjoys certain special treatments in international trade (such as exemption from certain commitments). Myanmar agrees to and adheres the basic principles of WTO but as yet has not rectified its commitments to WTO.

As Myanmar closely follows WTO basic principles, the draft Telecommunications law has been prepared in line with the WTO Reference Paper for Telecommunications Services. The New Law is in its final drafting stage.

Myanmar becomes a member of 10 countries Association of South East Asian Nations (ASEAN) in 23rd July 1997, and has subsequently signed all its agreement and declarations. One of the ultimate aims of the association is to establish a free trade area, namely the ASEAN Free Trade Area (AFTA). In approaching AFTA, all ASEAN countries are committed to liberalize telecommunications services as priority integration services, and ASEAN is negotiating to achieve the AFTA target. Liberalization of services under this scheme has been carried out in packages and as of 2009, Myanmar has made commitment to liberalize telecoms sectors with certain limitations. (The status of Myanmar's consolidates offer is attached.) The basic principle behind negotiation for liberalization under ASEAN Free Trade Area Agreement is WTO Guidelines. The same principle applies in negotiations for Free Trade Agreement with dialogue partners such as Australia. ASEAN has already concluded FTA with Australia.

ASEAN is unique in terms of each country's level of commitment to WTO. Differences in political, development levels and socio-economic conditions also pay important role in trade negotiations. Each country's prevailing domestic laws and regulations also should be carefully considered. Another important factor in telecoms services liberalization is technical interpretation (such as Independent regulator, interconnection, USO, rights- of- way etc.,) because each country has its own interpretations for such words, and they can be barriers to successful trade negotiations. 


\section{Conclusion}

Union of Myanmar, being a signatory to WTO and a member of ASEAN, has certain commitments to fulfill under these agreements. Telecommunications is one of the priority sectors for liberalization, and Ministry of Telecommunications, Posts and telegraphs has laid down guideline to the PTD for the liberalization of the telecom sector at the same time ensuring that national interest, security and soci-economic development are not undermined. Moreover, the new Telecoms Law will enable multi-telco competitive environment. Therefore trainings like this APT Workshop on Telecom Trade Rules will help officials responsible in telecoms trade negotiations with good knowledge and experience. 
The status of Myanmar's consolidates offer to AFAS 7th Package

\begin{tabular}{|c|c|c|c|}
\hline $\mathrm{NO}$ & W/120 SECTORS AND SUB-SECTORS & $\mathrm{CPC}$ & ACTUAL SCHEDULED SUBSECTORS \\
\hline & BUSINESS SERVICES & & \\
\hline & B. Computer and Related Services & & \\
\hline 12 & $\begin{array}{l}\text { Consultancy services related to the installation of computer } \\
\text { hardware }\end{array}$ & 841 & Same as specified \\
\hline 13 & Software implementation services & 842 & Same as specified \\
\hline 14 & Data processing services & 843 & Same as specified \\
\hline 15 & Data base services & 844 & Same as specified \\
\hline \multirow[t]{3}{*}{16} & Others & $845+849$ & Same as specified \\
\hline & COMMUNICATION SERVICES & & \\
\hline & C. Telecommunication services & & \\
\hline 49 & Voice telephone services & 7521 & \\
\hline 50 & Packet-switched data transmission services & $7523^{* *}$ & \\
\hline 51 & Circuit-switched data transmission services & $7523^{* *}$ & \\
\hline 52 & Telex services & $7523 * *$ & Same as specified \\
\hline 53 & Telegraph services & 7522 & Same as specified \\
\hline 54 & Fascimile services & $7521 * *+7529 * *$ & \\
\hline 55 & Private leased circuit services & $7522 * *+7523 * *$ & \\
\hline 56 & Electronic mail & $7523 * *$ & Same as specified \\
\hline 57 & Voice mail & $7523^{* *}$ & Same as specified \\
\hline 58 & On-line information and data base retrieval & $7523 * *$ & Same as specified \\
\hline 59 & Electronic data interchange (EDI) & $7523 * *$ & Same as specified \\
\hline 60 & $\begin{array}{l}\text { Enhanced / value-added facsimile services, incl. store and } \\
\text { forward, store and retrieve }\end{array}$ & $7523 * *$ & \\
\hline 61 & Code and protocol conversion & na & Same as specified \\
\hline 62 & $\begin{array}{l}\text { On-line information and / or data processing (incl transaction } \\
\text { processing) }\end{array}$ & $843^{* *}$ & Same as specified \\
\hline \multirow[t]{5}{*}{63} & Other & & $\begin{array}{l}\text { (a) Public telephone services (CPC 7521) } \\
\text { (b) Mobile telephone service (CPC 75213) }\end{array}$ \\
\hline & & & (c) Paging services (CPC 75291) \\
\hline & & & (d) Business network services (CPC 7522) \\
\hline & & & $\begin{array}{l}\text { (e) Data and message transmission services } \\
\text { (CPC 7523) }\end{array}$ \\
\hline & & & $\begin{array}{l}\text { (f) Telecommunication equipment mainte- } \\
\text { nance } \\
\text { services (CPC 75450) }\end{array}$ \\
\hline
\end{tabular}

